\title{
PROGRAM PENGEMBANGAN USAHA PRODUK INTELEKTUAL KAMPUS PUSAT LAYANAN FISIOTERAPI OLAHRAGA DAN KEBUGARAN
}

\author{
Endang Sepdanius $^{1^{*}}$, Donal Syafrianto ${ }^{2}$ \\ ${ }^{1}$ Program Studi Ilmu Keolahragaan Fakultas ilmu Keolahragaa Universitas Negeri Padang \\ *Email : endangsepdanius@ fik.unp.ac.id
}

\section{Informasi Artikel Abstrak}

Kata Kunci :

Pusat Layanan,

Fisioterapi,

Kebugaran

Diterima: $\mathrm{xx}-\mathrm{xx}-\mathrm{xxx}$

Disetujui: $\mathrm{xx}-\mathrm{xx}-\mathrm{xxx}$

Dipubikasikan: $\quad \mathrm{xx}-\mathrm{xx}-$ $\mathrm{xxx}$

\section{Keywords :}

Service Center,

Physiotherapy, Wellness
PPM PPUPIK bertujuan untuk mendorong Fakultas Ilmu Keolahragaan UNP menghasilkan produk jasa berupa penatalaksanaan fisioterapi dan kebugaran olahraga. Pelaksanaanya dikelola oleh kelompok dosen yang tegabung dalam laboratorium sport medicine. Mitra yang terlibat dalam kegiatan pengabdian ini adalah KONI Kota Pariaman Sumatera Barat. Waktu pelaksanaan kegiatan pengabdian ini adalah selama 6 bulan pelaksanaan kegiatan dari bulan Juni sampai dengan November 2020. Adapun metode yang dilakukan dalam kegiatan ini diantaranya adalah 1) Melengkapi sarana dan prasarana. 2) Mendesain program. 3) Melakukan perekrutan tenaga pembantu dan administrasi, 4) Pendampingan, 5) Pelayanan. Hasil yang dicapai yaitu Melengkapi sarana fisioterapi olahraga, sarana masase dan sarana kebugaran. Ada empat kegiatan layanan yaitu: a) fisioterapi olahraga, b) masase kebugaran, c) tes kebugaran fisik, d) program kebugaran fisik. Perekrutan tenaga pembantu dalam pelayanan fisioterapi olahraga, masase dan kebugaran dan tenaga administrasi. youtube dan Instagram digunakan untuk program promosi. Selama 3 bulan terkhir sudah ada 21 kunjungan ke pusat layanan fisioterapi olahraga.

\section{Abstract}

PPM PPUPIK aims to encourage the Faculty of Sports Science UNP to produce service products in the form of physiotherapy management and sports fitness kebugaran. The implementation is managed by a group of lecturers who are involved in the sports medicine laboratory. Partners involved in this service activity are KONI Pariaman city, West Sumatra. The implementation time of this service activity is for 6 months of carrying out activities from June to November 2020. The methods used in this activity include:1) Equip facilities and infrastructure, 2) Designing programs, 3) Recruiting assistant and administrative staff, 4) Accompaniment,5) Services. The results achieved were 1) equip sports physiotherapy facilities, massage facilities and fitness facilities. 2) There are four service activities, namely: a) sports physiotherapy, b) fitness massages, c) physical fitness tests, d) physical fitness programs. 3) 
Recruitment of assistants in sports physiotherapy services, massage and fitness and administrative staff. 4) YouTube and Instagram are used for promotional programs. 5) During the last 3 months there have been 21 visits to the sports physiotherapy service center.

\section{PENDAHULUAN}

Provinsi Sumatera Barat memiliki tingkat partisipasi dalam kegiatan olahraga yang baik. Baik itu berupa kegiatan olahraga kesehatan, pendidikan atau prestasi. Dalam pelaksaanaanya masih banyak dari para penggiat olahraga mengalimi gangguan pada fungsi tubuh terutama pada otot, tulang dan sendi(Banna et al., 2001). Gangguan ini diakibatkan karena kesalahan gerak(Paeslack, 1973), aktivitas gerak yang berlebihan, atau over training. Akibat dari ini semua bisa menyebabkan ketidaknyamanan anggota tubuh selema dalam keadaan istirahat(Zebrowska et al., 2019). Dalam penanganannya digunakan jasa fisioterapis olahraga untuk menurunkan masalah tersebut. Fisioterapis olahraga juga digunakan untuk rehabilitas gerak ruang sendi yang terbatas, spasme dan penguatan otot-otot tertentu serta kegunaan lainnya(Arovah, 2010). Rehabilitasi merupakan suatu upaya untuk mengembalikan seseorang ke kondisinya semula atau ke kondisi yang lebih baik daripada kondisinya sekarang(Hariandja, 2013). Dengan menerapkan kepatuhan terhadap pelatihan fisik yang bertujuan untuk mengembalikan atau melakukan rehabilitas terhadap masalah otot(Kolt et al., 2007). Selain itu latihan sebagai sebuah alat terapi fisik untuk meningkatkan derjat kebugaran telah pasca rehabilitas fisik(Permata, 2018). Kemudian kepatuhan merupakan sebuah usaha yang sangat berperan penting dalam penatalaksaan rehabilitas pasca injuri dengan pendekatan fisioterapi(Marshall et al., n.d.).

Fisioterapi olahraga tidak berdiri sendiri dalam pelaksaanaanya namun dibarengi dengan program lain yang berkaitan satu sama lainnya. Misalnya kesahatan gerak bagi orang dengan berat badan berlebih yang merupakan faktor penyebab ketegangan otot dan membuat orang tersebut susah untuk bergerak secara normal. Kondisi ini akan di tangani terlebih dahulu dengan fisioterapis olahraga kemudian dianjurkan untuk mengikuti program penurunan berat badan. Atau kasus lain misalnya orang yang ingin mengetahui status kebugaran maka program lainnya bisa ditawarakan yaitu program kebugaran saja. Tidak harus mengikuti kegiatan fisioterapi olahraga atau program penurunan berat badan. Biasanya dilakukan untuk orang-orang yang mempersiapkan diri untuk pergi haji, atau melaksanakan kegiatan kedinasan. Jadi berdasarkan fungsi dan manfaat, pusat layanan ini memiliki peluang besar untuk berkembang di Sumatera Barat.

Pertimbangan kenapa ini bisa menjadi peluang besar adalah intensitas masyarakat terhadap kegiatan olahraga sangat tinggi. Terlihat dari event-event olahraga yang terselenggara di Sumatera Barat diadakan sepanjang tahun baik yang resmi maupun yang bersifat open tournament untuk masingmasing cabang olahraga. Kegiatan olahraga masyarakat yang saat sekarang yang sedang popular di 
masyarakat. Fisioterapi berpeluang untuk membantu dalam mengatasi masalah baik yang bisa terjadi dalam kegiatan tersebut, oleh karena itu, promosi dan pemasaran yang tepat perlu diterapkan untuk mendapatkan pasar yang lebih baik dari peluang yang ada(Amanah, 2015).

Pelayanan fisioterapis olaharaga di Kota Padang khususnya dan Sumatera Barat umumnya belum terliihat ada. Dari rumah sakit tingkat daerah maupun tingkat provinsi hanya menyediakan fisioterapi umum. Selain itu, survey yang dilakukan di tempat-tempat kebugaran juga tidak memiliki layanan fisioterapi olahraga. Di pusat kebugaran hanya melayani pendampingan kegiatan kebugaran. Berdasarkan data yang di dapat tersebut maka pusat layanan fisioterapi olahraga sangat cocok dikembangkan dalam kegaitan PPUPIK di Fakultas Ilmu Keolaharagaan

Program terapi dan rehabilitas olahraga akan menangani masalah-masalah yang terkait dengan cidera olahraga baik itu dislokasi. Porgram kebugaaran akan menangani pemeriksaan kebugaran, membuat program latihan, dan mendampingi kegiatan latihan. Program penurunan berat badan dan obesitas dengan memberikan layanan penatalaksanaan kegiatan penurunan berat badan, membuat program latihan dan mendampingi selama program penatalaksanaan penuruan berat badan /obesitas berjalan.

Proses dan system yang dipilih untuk menjalankan kegaitan ini yaitu menggandengan instansi keolahragaan dan instansi kesehatan yang membutuhkan penanganan terapi olahraga dan kesehatan terkait dengan kebugaran. Akan dilakukan penjajakan MoU dengan instansi tersebut misalnya KONI Sumatera Barat dan KONI kabupaten/kota se Sumatera Barat, pengurus cabang olahraga yang ada di seluruh Sumatera Barat serta rumah sakit baik tingkat daerah maupun tingkat provinsi. Sistem yang dijalankan akan dituangkan dalam bentuk buku. kemudian buku ini nantinya bisa dijadikan sebagai HKI

Dampak dengan terbntuknya pelayanan fisioterapis olahraga ini memberikan warna baru di Indonesia dan Sumatera Barat khususnya dalam mengatasi masalah cidera olahraga dan kebugaran. Sedangkan manfaat yang didapat membuka peluang usaha baru bagi sehingga terciptanya lapangan pekerjaan bagi mahasiswa yang ingi bergabung serta kompeten dalam bidang tersebut.Bahwasanya masih banyak peluang usaha yang terkait dengan fisioterapis yang bisa dikembangkan(Santoso, 2007).

Adapun permasalah yang dihadapi oleh dosen yang ada diperguruan tinggi program studi ilmu keolahragaan Univeristas Negeri Padang yaitu: 1) Masih kurang kemampuan dalam memanajemen usaha dalam upaya komersialisasi kompetensi yang dimiliki dan dibutuhkan stakeholder, 2) Belum memiliki peluang untuk mendirikan pusat usaha sesuai dengan kompetensi keahlian, 3) Dosen selama ini hanya berinteraksi dengan mahsiswa sehingga hampir tidak pernah mempraktekan lansung penanganan masalah yang memang ditemukan dimasyarakat, 4) Belum ada tempat usaha yang didirikan oleh institusi pendidikan di Fakultas Ilmu Keolahragaan yang menampung mahasiswa lulusan itu sendiri, 5) Belum diketahui oleh banyak stake holder bahwa fakultas ilmu keolahraagaan memiliki kemampuan dalam penganaan masalah fisioterapi olarhaga dan kebugaran. 
Solusi yang ditawarkan adalah sebagai berikut: Merancang laboratorium sport medicine menjadi pusat layanan fisioterapi olahraga dan kebugaran sehingga mampu memberi peluang bagi dosen yang bersangkutan untuk lansung menjalankan usaha dalam bidang fisioterapi olahraga dan kebugaran

\section{METODE PELAKSANAAN}

Mitra yang terlibat dalam kegiatan pengabdian ini adalah KONI Kota Pariaman Sumatera Barat. Waktu pelaksanaan kegiatan pengabdian ini adalah selama 6 bulan pelaksanaan kegiatan dari bulan Juni sampai dengan November 2020. Adapun metode yang dilakukan dalam kegiatan ini diantaranya adalah 1) Melengkapi sarana dan prasarana penunjang kegiatan pelayananan seperti ruangan yang kondusif, perlengkapan penatalaksanaan fisioterapai olahrag dan semua terkait dengan promosi. 2) Mendesain program layanan fisioterapi olahraga dan kebugaran terdiri dari a) Penanganan fisioterapi olahraga, b) masase kebugaran, c) tes kebugaran fisik, d) program kebugaran fisik. 3) Melakukan perekrutan tenaga pembantu dan administrasi, 4) Melakukan pendampingan manajemen, Pendampingan pengurusan izin praktek, dan pendampingan dalam usaha promosi, 5) Melakukan pelayanan.

\section{HASIL DAN PEMBAHASAN}

Pengabdian kepada masyarakat adalah usaha untuk menyebarluaskan ilmu pengetahuan, teknologi, dan seni kepada masyarakat. Kegiatan tersebut harus mampu memberikan suatu nilai tambah bagi masyarakat, baik dalam kegiatan ekonomi, kebijakan, dan perubahan perilaku (sosial). Uraikan bahwa kegiatan pengabdian telah mampu memberi perubahan bagi individu/masyarakat maupun institusi baik jangka pendek maupun jangka panjang.

\section{Melengkapi sarana dan prasarana}

Pengembangan sarana dan prasarana pusat layanan merupakan tujuan pada tahap awal ini. Pengembangan dilakukan untuk meningkat pelayanan dan kemapanan pusat layanan untuk melayani pasien yang membutuhkan. Ada tiga sasaran yang dibangun dan dikembangkan dalam kegiatan ini. Sarana fisioterapi olahraga, sarana masase dan sarana kebugaran. Sarana dan prasarana fisioterapi diantaranya adalah melakukan perbaikan tempat seperti menyediakan ruangan dengan fasilitas lengkap diantaranya ruangan dengan penuh karpet, wallpaper setengah dinding, pencahayaan dan pengatur suhu, plang nama, barner dan spanduk. 


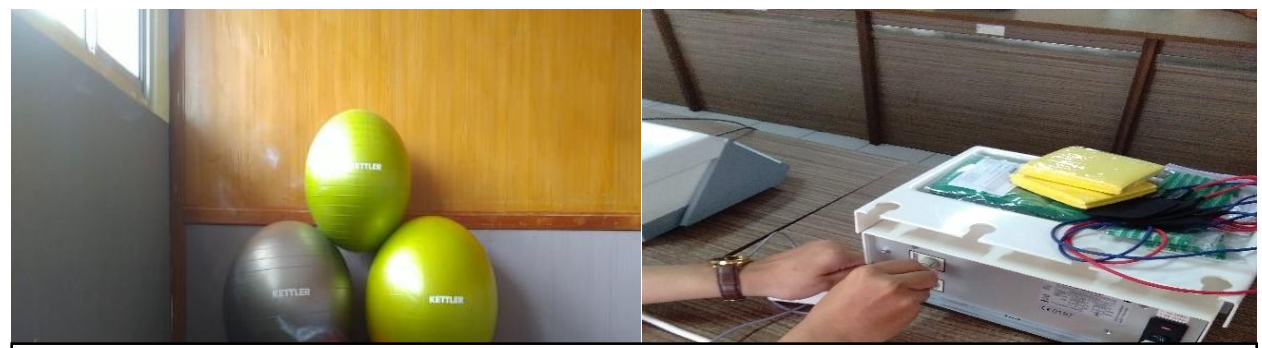

Gambar 1. Peralatan lengkap: bosu ball, gymball, medicine ball, dumbbell dan combination electrical stimulation current and ultrasound

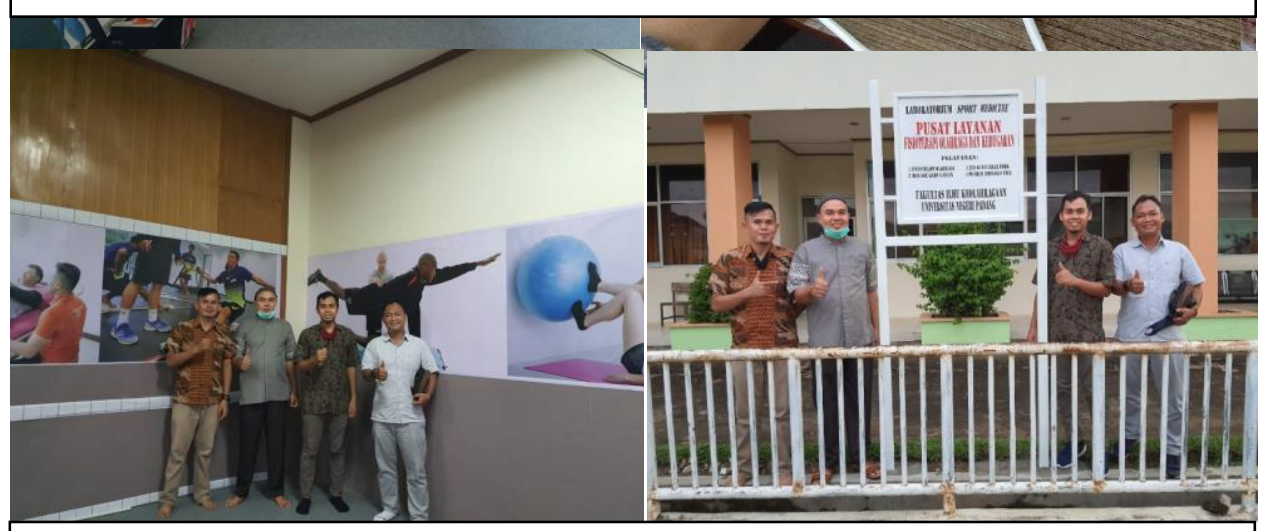

Gambar 2. Ruangan dengan penuh karpet, wallpaper setengah dinding, pencahayaan dan pengatur suhu.
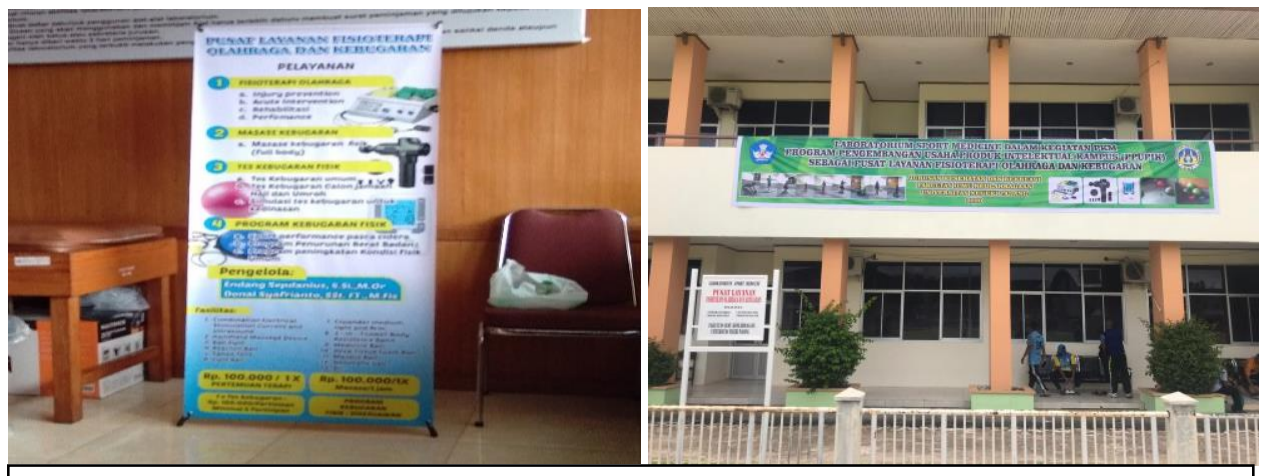

Gambar 3. Plang nama, barner dan spanduk

Program tes kebugaran dan Program kebugaran dilakukan dengan mengedepankan labor terintegrasi. Artinya, program yang diberikan kepada pasien bisa saja melibatkan fasilitas dan 
labor lainya selingkungan fakultas ilmu keolahragaan diantaranya. Track atletik, ruang fittnes centre, kolam renang, dan ruang masase.

\section{Desain program layanan fisioterapi olahraga dan kebugaran}

Ada empat kegiatan layanan yang disediakan dalam kegiatan pusat layanan fisioterapi olahraga yaitu: a) fisioterapi olahraga, b) masase kebugaran, c) tes kebugaran fisik, d) program kebugaran fisik.

Tabel 1. Program Layanan Fisioterapi olahraga dan kebugaran

\begin{tabular}{lll}
\hline No & \multicolumn{1}{c}{ Pusat Layanan } & \multicolumn{1}{c}{ Layanan } \\
\hline 1 & Fisioterapi olahraga & Injury prevention \\
\cline { 3 - 3 } & & Acute intervention \\
\cline { 3 - 3 } & Rehabilitas & Performance \\
\hline 2 & Masase kebugaran & Masase kebugaran manual \\
\cline { 3 - 3 } & Tes kebugaran fisik & Masase kebugaran menggunakan alat (gun masase) \\
\cline { 3 - 3 } & & tes kebugaran fisik umum \\
\cline { 3 - 3 } & & tes kebugaran calon Jemaah haji dan umroh \\
\hline 4 & Program kebugaran fisik & sport performance pascacidera \\
\cline { 3 - 3 } & & program penurunan berat badan \\
\cline { 3 - 3 } & & program peningkatan kondisi fisik \\
\hline
\end{tabular}

\section{Melakukan perekrutan tenaga pembantu dan administrasi}

Sementara kegiatan pengabdian berjalan dilakukan perekrutan tenaga pembantu dan administrasi. Perekrutan tenaga pembantu untuk membantu dalam pelayanan fisioterapi olahraga, masase dan kebugaran dan tenaga administrasi untuk pengaruran jadwal dan pendaftaran pasien.

Pendampingan manajemen, Pendampingan pengurusan izin praktek, dan pendampingan dalam usaha promosi.

Dalam kegiatan ini pengelola pusat layanan fisioterapi olahraga dan kebugaran didampingi oleh pemateri-pemateri dalam melaksanakan kegiatan seperti dalam pendampingan manajemen pusat layanan, pendampingan dalam pengurusan izin praktek dan pendampingan 
dalam usaha promosi produk usaha yang dihasilkan. Adapun pemateri serta materi yang disampaikan serta kegiatan pendampingan yang dilakukan selama kegiatan disampaikan pada table berikut:

Tabel 2. Pemateri, materi serta kegiatan pendampingan

\begin{tabular}{|c|c|c|c|}
\hline No & Pemateri & Materi & Pendampingan \\
\hline 1 & Pemateri 1 & $\begin{array}{l}\text { Manajemen } \\
\text { pengelolaan } \\
\text { layanan }\end{array}$ & $\begin{array}{l}\text { a. Pendampingan dalam pengelolaan } \\
\text { administrasi } \\
\text { b. Pendampingan dalam manajemen } \\
\text { perekrutan tenaga pembantu dan } \\
\text { administrasi } \\
\text { c. Pendampingan dalam manajemen } \\
\text { keuangan }\end{array}$ \\
\hline 2 & Pemateri 2 & $\begin{array}{l}\text { Pengemasan dan } \\
\text { Promosi Produk Usaha } \\
\text { Intelektual Kampus }\end{array}$ & $\begin{array}{l}\text { a. Pendampingan dalam pengelolaan } \\
\text { promosi menggunakan media sosial } \\
\text { b. Pendampingan dalam pengemasan } \\
\text { produk usaha }\end{array}$ \\
\hline 3 & Pemateri 3 & Surat Ijin Praktek & $\begin{array}{l}\text { Pendampingan dalam pengurusan } \\
\text { izin praktek fisioterapi olahraga }\end{array}$ \\
\hline
\end{tabular}

Media dan usaha yang digunakan untuk promosi pusat layanan fisioterapi olahraga dan kebugaran.

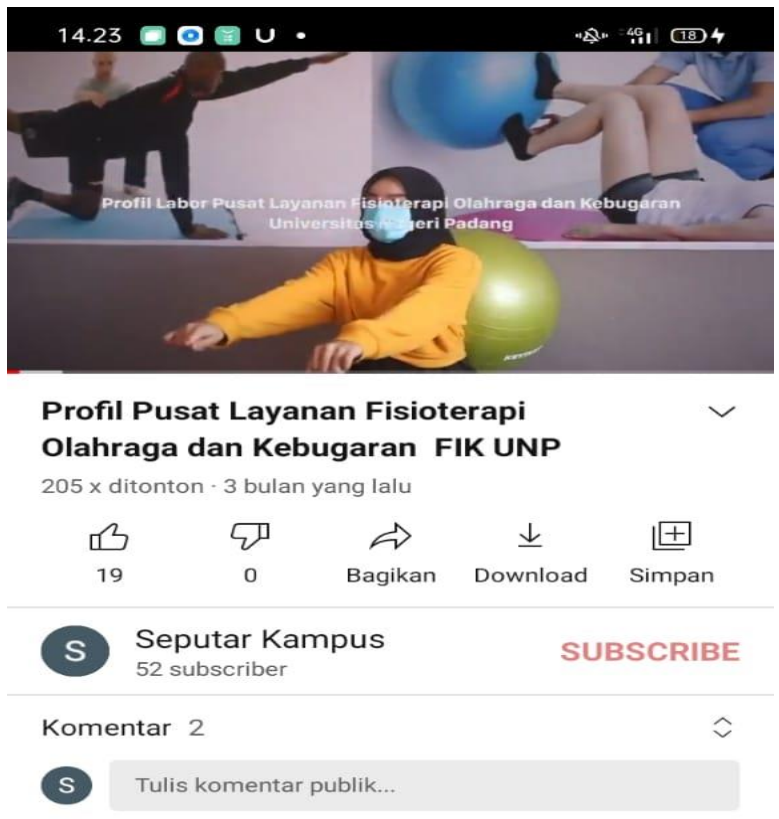

Gambar 4. Profil Pusat Layanan Fisioterapi di youtube Channel

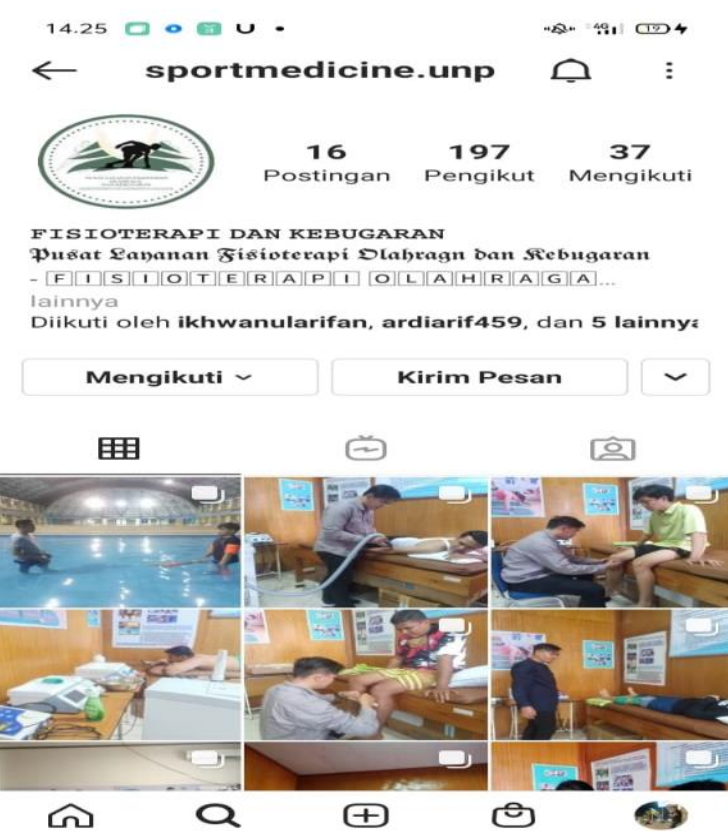

Gambar 5. Promosi Menggunakan Media Instragram 
Melakukan pelayanan dilakukan dengan mengedepankan standar protokol kesehatan covid 19, dengan menyediakan fasilitas cuci tangan dan masker serta handsanitaizer. Pelayanan utama mengacu pada standar operasional prosedur sesuai dengan kebutuhan dan keluhan pasien yang datang. Berikut alur pelayanan yang wajib diterapkan:

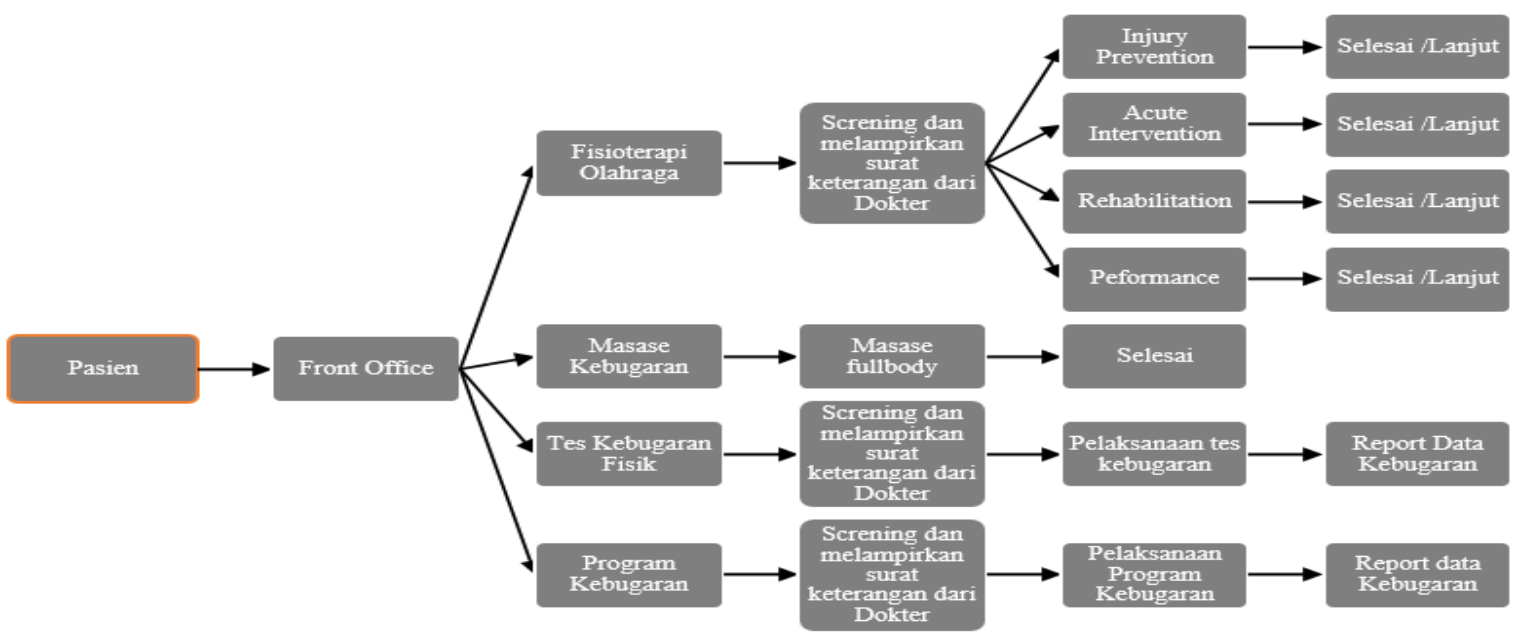

Gambar 4. standar operasional prosedur pelayanan pusat layanan fisioterapi olahraga dan kebugaran

Selain itu, manajemen dari kegiatan pelayanan juga memiliki standar operasional yang perlu ditaati selama kegiatan berlansung. Koordinasi antara ketua labor dalam hal ini mengelolah pusat layanan mempunyai koordinasi dengan jurusan dan fakultas. Berikut merupakan alur koordinasi yang perlu dilakukan oleh pengelola dengan jurusan dan fakultas melalui laboratorium sport medicine.

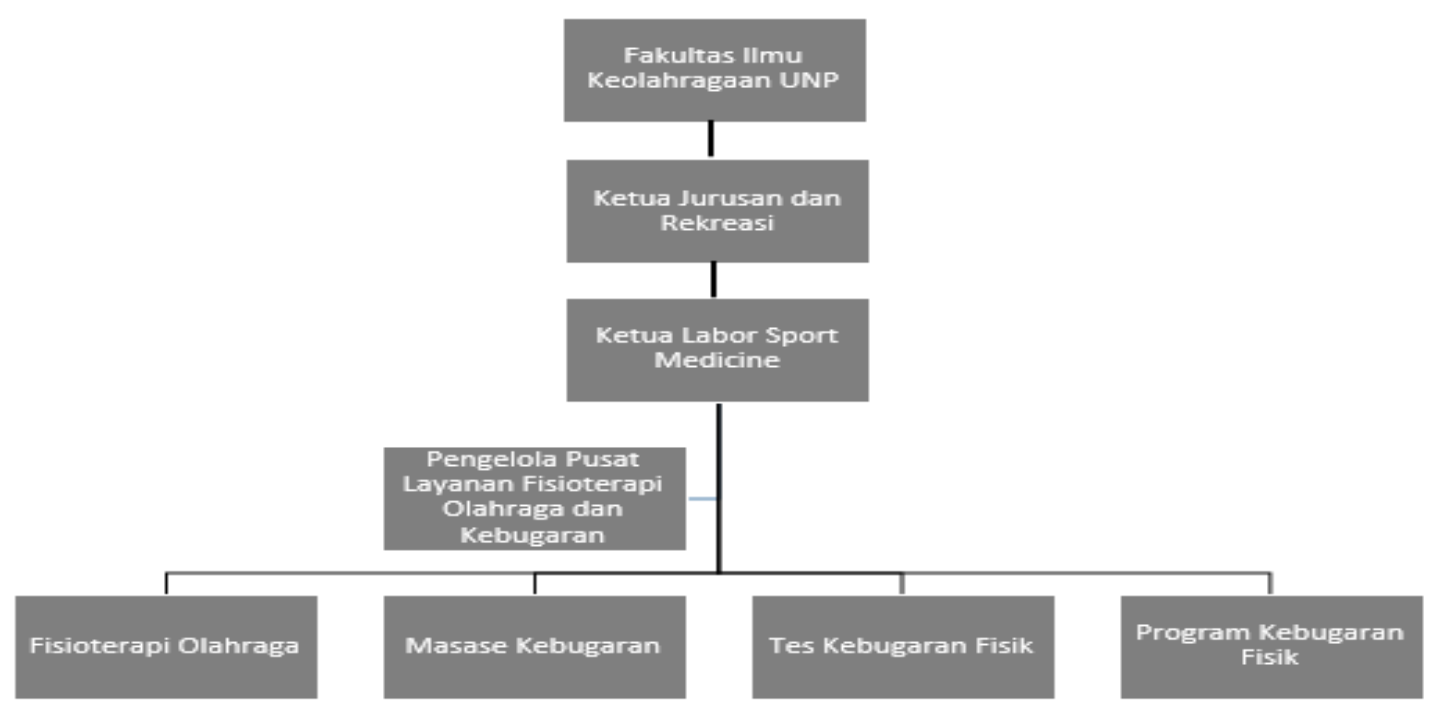

Gambar 5. Alur Koordinasi dalam pusat layanan fisioterapi olahraga dan kebugaran 
Berikut ditampilkan jumlah pengunjung dalam 3 bulan terakhir.

Tabel 3. pengunjung selama 3 bulan terakhir

\begin{tabular}{llllc}
\hline No & Kunjungan & Jumlah & Keterangan & Kunjungan \\
\hline 1 & Fisioterapi & 16 & Paket Terapi & 21 \\
\hline 2 & Kebugaran & 2 & Konsultasi & \\
\hline
\end{tabular}

\section{KESIMPULAN}

Berdasarkan kegiatan yang telah dilaksanakan maka dapat ditarik beberapak kesimpulan secara garis besar. Pertama dalam merancang sebuah labor yang kompeten dalam pelayanan harus memenuhi standar pelayana yang ditawarkan. Kedua, playanan yang ditawarkan pada pusat layanan harus memang berdasarkan dari hasil kajian dan focus grup discussion. Ketiga, lakukan perekrutan untuk tenaga pembantu berdasar kebutuhan pusat layanan dan usahakan memang hasil dari lulusan dari jurusan yang memiliki kridibilatas dalam meluluskan mahasiswa yang kompeten. Keempat, libatkan dosen-dosen yang kompeten sebagai pemateri dan pendamping dalam kegiatan selama pengembangan pusat layanan. Kelima, lakukan pelayanan berlandaskan pada standar operasional prosedur yang sudah ditetapkan sebelum pelayanan ini dimulai.

\section{UCAPAN TERIMAKASIH}

Penulis mengucapkan terima kasih kepada $\mathrm{xxx}$ yang telah memberi dukungan financial terhadap pengabdian ini.

\section{DAFTAR PUSTAKA}

Amanah, S. (2015). Peranan Strategi Promosi Pemasaran Terhadap Peningkatan Volume Penjualan. Jurna Lentera Kajian Keagamaan, Keilmuan, Dan Teknologi, 13(1), 55-66.

Arovah, N. I. (2010). Dasar-dasar fisioterapi pada cidera olahraga.

Banna, D. Al, Ft, S. S. T., Fis, M., Puskesmas, F., \& Sleman, G. I. (2001). OLAHRAGA Oleh: Pemeriksaan kesehatan awal Oleh Fisioterapi.

Hariandja, J. R. O. (2013). TEKNOLOGI TERJANGKAU UNTUK PENDERITA STROKE DI INDONESIA.

Kolt, G. S., Brewer, B. W., Pizzari, T., Schoo, A. M. M., \& Garrett, N. (2007). The Sport Injury Rehabilitation Adherence Scale: a reliable scale for use in clinical physiotherapy. Physiotherapy, 93(1), 17-22. https://doi.org/https://doi.org/10.1016/j.physio.2006.07.002

Marshall, A., Donovan-Hall, M., \& Ryall, S. (n.d.). An Exploration of Athletes' Views on Their Adherence to Physiotherapy Rehabilitation After Sport Injury. Journal of Sport Rehabilitation, 21(1), 18-25. https://doi.org/10.1123/jsr.21.1.18 10.1123/jsr.21.1.18 
Paeslack, V. (1973). REHABILITATION VON PATIENTEN MIT PARAPLEGIEN. Rehabilitation, 12(3).

Permata, A. (2018). Pelatihan Interval Intensitas Tinggi Lebih Meningkatkan Kebugaran Fisik Daripada Senam Aerobik High Impact Pada Mahasiswa Program Studi D-Iii Fisioterapi Universitas Abdurrab. Jurnal Ilmiah Fisioterapi, 1(1), 1-10.

Santoso, T. B. (2007). Menumbuhkembangkan jiwa kewirausahaan mahasiswa fisioterapi melalui kuliah kerja usaha pembuatan alat bantu ambulasi jalan pasien. WARTA, 10(2), 136-147.

Zebrowska, A., Trybulski, R., Roczniok, R., \& Marcol, W. (2019). Effect of Physical Methods of Lymphatic Drainage on Postexercise Recovery of Mixed Martial Arts Athletes. Clinical Journal of Sport Medicine, 29(1). https://doi.org/10.1097/JSM.0000000000000485 